UDC 551.510.535 + 550.388

\title{
IONOSPHERIC RESPONSE TO AGW PROPAGATION DETECTED USING GNSS MEASUREMENTS AND COHERENT HF SOUNDING OVER "VERNADSKY" AND "PALMER" ANTARCTIC STATIONS
}

\author{
A. A. Sopin' ${ }^{1}$ Yu. M. Yampolski ${ }^{1}$, V. V. Paznukhov ${ }^{2}$, S. B. Kascheev ${ }^{1}$, A. V. Koloskov ${ }^{1}$, I. I. Pikulik ${ }^{1}$, \\ A. V. Zalizovski ${ }^{1}$ and A. S. Kashcheyev ${ }^{1,3}$ \\ ${ }^{1}$ Institute of Radio Astronomy of National Academy of Sciences of Ukraine, 4 Mystetstv St., Kharkiv, \\ Ukraine,sopin@rian.kharkov.ua \\ 2 Institute for Scientific Research, Boston College, 140 Commonwealth Ave., Chestnut Hill, MA 02467, \\ US,vadym.paznukhov@bc.edu \\ ${ }^{3}$ The Abdus Salam International Centre for Theoretical Physics, Telecommunications/ICT for \\ Development Laboratory, Trieste, Italy, akashche@ictp.it
}

\begin{abstract}
The work presents results of the diagnostics of travelling ionospheric disturbances (TIDs) over the Antarctic Peninsula obtained by using two different techniques. The first method is based on ground-based multipositional GNSS TEC measurements, and the second one is bistatic coherent ionospheric HF radio sounding between "Akademik Vernadsky" and "Palmer" Antarctic stations. A comparison of Doppler frequency shifts of the probe HF signal received at "Palmer" station with the dynamics of TEC variations has been made. Quasi-periodic variations associated with the propagation of TIDs were registered simultaneously in both types of the data. A case study performed in this paper has shown that the parameters of the ionospheric disturbance estimated by two methods are in a good agreement, given a specific choice of ionospheric pierce point (IPP) trajectories of GNSS links near the reflection point of the HF probing signal and TID motion direction collinear to the radiopath and perpendicular to IPP trajectories.
\end{abstract}

Key words: GNSS diagnostics, HF radio sounding, TID, TEC, ionospheric irregularities.

Іоносферний відгук на поширення АГХ за даними ГНСС вимірювань і когерентного ВЧ зондування над антарктичними станціями «Вернадський» $\mathbf{i}$ «Палмер»

А. О. Сопін, Ю. М. Ямпольський, В. В. Пазнухов, С. Б. Кащеєв, О. В. Колосков, І. І. Пікулік, А. В. Залізовський, А. С. Кащеєв

Реферат. Представлено результати діагностики рухомих іоносферних збурень (РI3) над Антарктичним півостровом, які було отримано двома різними методами. Перший метод базується на наземних багатопозиційних ГНСС вимірюваннях повного електронного вмісту (ПЕВ), а другий - це двопозиційне когерентне ВЧ радіозондування іоносфери між антарктичними станціями «Академік Вернадський» $\mathrm{i}$ «Палмер». Проведено порівняння варіацій доплерівського зсуву частоти пробного ВЧ сигналу, прийнятого на станції «Палмер», з динамікою варіацій ПЕВ. Квазіперіодичні варіації, асоційовані з поширенням PI3, 
було зареєстровано одночасно в обох типах даних. Розглянутий у роботі випадок показав, що параметри іоносферного збурення, отримані двома методами, добре узгоджуються, враховуючи спеціальний вибір траєкторій підіоносферних точок ГНСС супутників поблизу точки відбиття пробного ВЧ сигналу, і поширенні РІ3 в напрямку колінеарному радіотрасі та перпендикулярному траєкторії руху підіоносферної точки.

\section{Ионосферный отклик на распространение АГВ по данным ГНСС измерений и когерентного ВЧ зондирования над антарктическими станциями «Вернадский» и «Палмер»}

А. А. Сопин, Ю. М. Ямпольский, В. В. Пазнухов, С. Б. Кащеев, А. В. Колосков, И. И. Пикулик, А. В. Зализовский, А. С. Кащеев.

Реферат. Представлены результаты диагностики перемещающихся ионосферных возмущений (ПИВ) над Антарктическим полуостровом, которые были получены двумя разными методами. Первый метод основан на наземных многопозиционных измерениях полного электронного содержания (ПЭС), а второй - это двухпозиционное когерентное ВЧ радиозондирование ионосферы между антарктическими станциями «Академик Вернадский» и «Палмер». Проведено сравнение вариаций доплеровского сдвига частоты пробного ВЧ сигнала, принятого на станции «Палмер» с динамикой вариаций ПЭС. Квазипериодические вариации, ассоциируемые с распространением ПИВ, были зарегистрированы одновременно в обоих типах данных. Рассмотренный в работе случай показал, что параметры ионосферного возмущения, полученные двумя методами, хорошо согласуются, учитывая специальный выбор траекторий подионосферных точек ГНСС спутников вблизи точки отражения пробного ВЧ сигнала и движении ПИВ в направлении, коллинеарном радиотрассе и перпендикулярном траектории распространении подионосферной точки.

\section{Introduction}

Quasi-periodic fluctuations of ionospheric electron density caused by propagation of atmospheric gravity waves (AGW) represent special interest for investigations of dynamic processes in the ionosphere (Hocke, 1996). Travelling ionospheric disturbances (TIDs) play a significant role in the ionospheric dynamics and the Antarctic Peninsula region is one of the most interesting places for their investigation, since this area is a known hot spot of gravity wave activity (Grocott et al., 2013). It is one of the most meteorologically active regions on the Earth, which makes it a good place for studying troposphereionosphere interaction and propagation of weather disturbances from the ground level to ionospheric heights (Yampolski et al., 2004; Zalizovski et al., 2007). Also, this region is located at middle geomagnetic latitudes where background ionospheric variations are low, which facilitates detecting ionospheric responses to AGW propagation.

At the Ukrainian Antarctic station "Akademik Vernadsky" (UAS) the vertical ionospheric sounding has been being carried out for more than 50 years. Routine measurements of total electron content (TEC) using L-band signals of the global navigation satellite system (GNSS) began in 2009 (permanent GPS station VNAD). These data together with observations from PALM and DUPT GNSS ground stations (see Fig. 1) make it possible to detect and reconstruct parameters of wavelike ionospheric irregularities. A statistical analysis of the characteristics of acoustic gravity waves (AGW)/travelling ionospheric disturbances registered in the Antarctic Peninsula region during several years has been performed by the co-authors earlier. The primary diurnal and seasonal occurrence patterns and main characteristics of AGW/TIDs have been determined for this region (Sopin et al., 2012; Galushko et al., 2016).

In January - March of 2004 test measurements of TID parameters were performed on an HF radio link between UAS and "Henrik Arcktowski" (Poland) Antarctic stations (Galushko et al., 2007). It was shown that TID characteristics, such as period, propagation direction and velocity can be obtained with the help of the frequency-and-angular (FAS) HF sounding technique (Beley et al., 1995; Paznukhov et al., 2012). To continue the study of TID phenomena a new data-acquisition system for bistatic coherent HF sounding of the ionosphere was installed in 2015. HF transmitter operating within frequency range $\left(f_{\mathrm{w}}\right)$ from 2 to $10 \mathrm{MHz}$ was deployed at the UAS and receiving system was installed at the U.S. Antarctic station "Palmer" establishing approximately $53 \mathrm{~km}$ long radiolink. In the present study variations of the parameters of the ionospherically reflected HF signal on this quasi-vertical radio path have been used to estimate TID characteristics and to compare them with the results of the TID diagnostics obtained from multisite GNSS TEC measurements. 


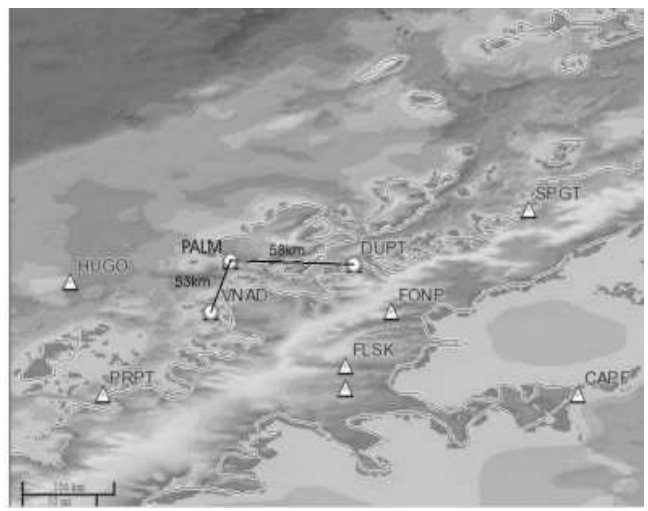

Fig. 1. Location of GNSS stations in the Antarctic Peninsula region (http://sopac.ucsd.edu/map.shtm).

\section{Techniques and Instruments}

\section{GPS TEC measurements}

In this work data from four permanent GPS stations: "Palmer" (PALM, 64.78 $\left.\mathrm{S}, 64.05^{\circ} \mathrm{W}\right)$, "Vernadsky" (VNAD, 65.25 $5^{\circ}, 64.25^{\circ} \mathrm{W}$ ), "Duthiers Point" (DUPT $\left.64.81^{\circ} \mathrm{S}, 62.82^{\circ} \mathrm{W}\right)$, and "Prospect Point"(PRPT $\left.66.01^{\circ} \mathrm{S}, 65.34^{\circ} \mathrm{W}\right)$ have been used.

The parameters of travelling ionospheric disturbances, such as velocity and propagation direction, are estimated using "dynamic approach" to the problem of TIDs diagnostics using GNSS measurements proposed by Galushko et al. (2016). This method is based on using the space and time derivatives of TEC variations $I(x, y, t)$ calculated at the penetration points with time varying horizontal coordinates $x_{p}(t), y_{p}(t)$. If TEC perturbation moves in a frozen-in manner and has a plane amplitude front, it can be represented in the following form:

$$
I(x, y, t)=\mathrm{I}(x \sin \alpha+y \cos \alpha-V) .
$$

The disturbance propagation direction $\alpha$ (azimuth) and its velocity $\mathrm{V}$ can then be found as:

$$
\begin{gathered}
\sin \alpha(t)=\gamma_{x}(t) / \gamma(t) \text { and } \cos \alpha(t)=\gamma_{y}(t) / \gamma(t), \\
V(t)=\frac{1}{\gamma(t)}\left[\gamma_{x}(t) \frac{d x_{p}(t)}{d t}+\gamma_{y}(t) \frac{d y_{p}(t)}{d t}-I^{\prime}(t)\right], \\
\gamma(t)= \pm \sqrt{\gamma_{x}^{2}(t)+\gamma_{y}^{2}(t)},
\end{gathered}
$$

where spatial $\gamma_{x^{\prime}}, \gamma_{y}$ and temporal $I^{\prime}$ gradients can be numerically estimated as $\left(I_{i}, x_{i}, y_{i}(i=1,2,3)-\right.$ TEC variations and coordinates of corresponding observation point (GNSS station), respectively):

$$
\begin{gathered}
I_{1}^{\prime}\left(t_{n}\right) \approx \frac{I_{1}\left(t_{n}\right)-I_{1}\left(t_{n-1}\right)}{\Delta t}, \\
\gamma_{x}\left(t_{n}\right) \approx \frac{y_{3} \cdot\left(I_{2}\left(t_{n}\right)-I_{1}\left(t_{n}\right)\right)-y_{2} \cdot\left(I_{3}\left(t_{n}\right)-I_{1}\left(t_{n}\right)\right)}{x_{2} y_{3}-x_{3} y_{2}}, \\
\gamma_{y}\left(t_{n}\right) \approx \frac{x_{2} \cdot\left(I_{3}\left(t_{n}\right)-I_{1}\left(t_{n}\right)\right)-x_{3} \cdot\left(I_{2}\left(t_{n}\right)-I_{1}\left(t_{n}\right)\right)}{x_{2} y_{3}-x_{3} y_{2}} .
\end{gathered}
$$


A. A. Sopin, Yu. M. Yampolski, V. V. Paznukhov, S. B. Kascheev,

A. V. Koloskov, I. I. Pikulik, A. V. Zalizovski, and A. S. Kashcheyev

IONOSPHERIC RESPONSE TO AGW PROPAGATION DETECTED USING GNSS MEASUREMENTS AND COHERENT HF SOUNDING OVER "VERNADSKY” AND “PALMER” ANTARCTIC STATIONS

\section{HF Doppler measurement system}

The system used for the bistatic coherent ionospheric sounding consists of the probing HF transmitter deployed at UAS and two coherent receivers located at "Vernadsky" and "Palmer" stations installed in May 2015. The distance between stations is approximately $53 \mathrm{~km}$ and the bearing is almost meridional (azimuth $\sim 10^{\circ}$ ). The transmitter is based on a commercial transceiver "ICOM-718". Fig. 2a shows the transmitting system which includes antenna tuner, power supply and a specially designed modulator. This system can be controlled using a personal computer that allows advance scheduling of frequencies and operating modes. A half-wave folded dipole antenna used for the transmission is mounted on top of the main station building (Fig. 2b).

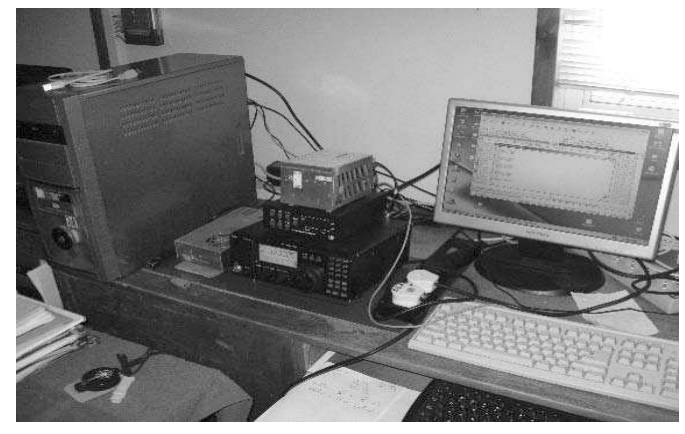

a)

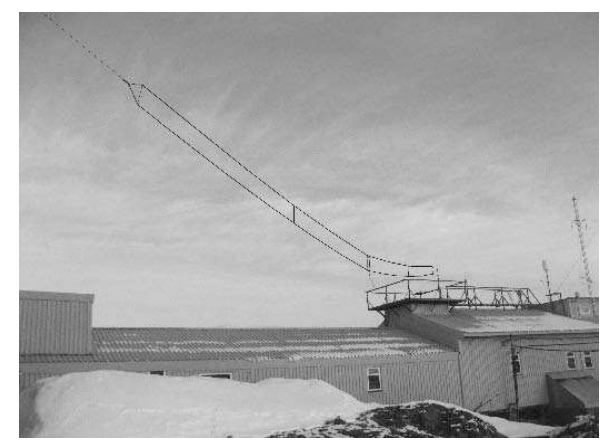

b)

Fig. 2. Transmitting system (a) and half-wave folded dipole antenna at "Vernadsky" station (b).

The receiving loop antenna was deployed at UAS on top of the "VLF hut" $400 \mathrm{~m}$ away from the transmitter (Fig. 3). Similar active loop antennas were installed at the "Palmer" station.

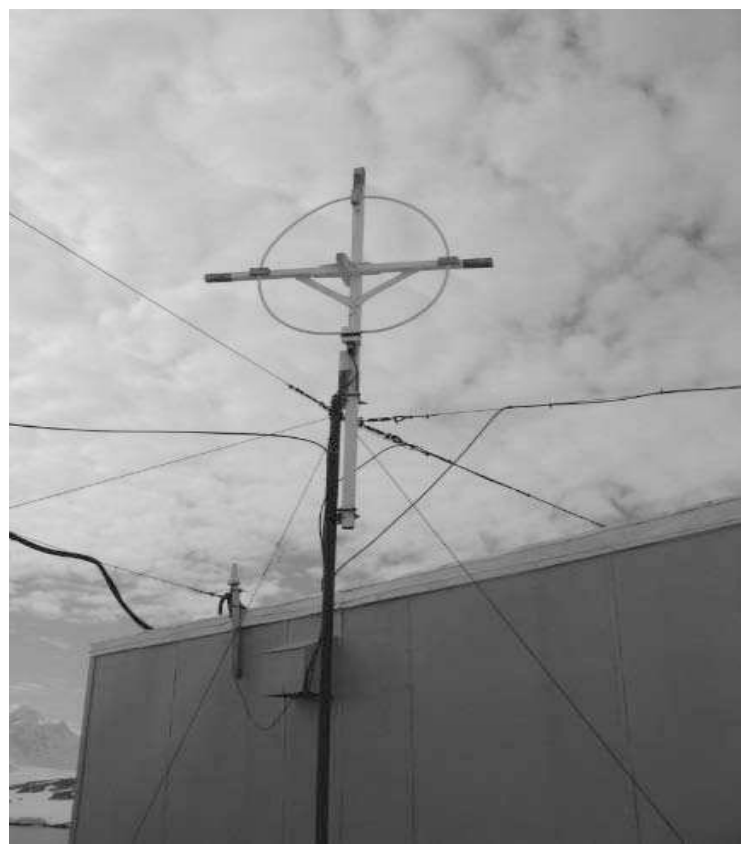

Fig. 3. Receive loop HF antenna over the "VLF hut" at UAS.

The receiving system at "Palmer" station is a chain of 3 coherent receivers (Fig. 4) which allows measuring angles of arrival and Doppler frequency shift (DFS) of the probing signal. 


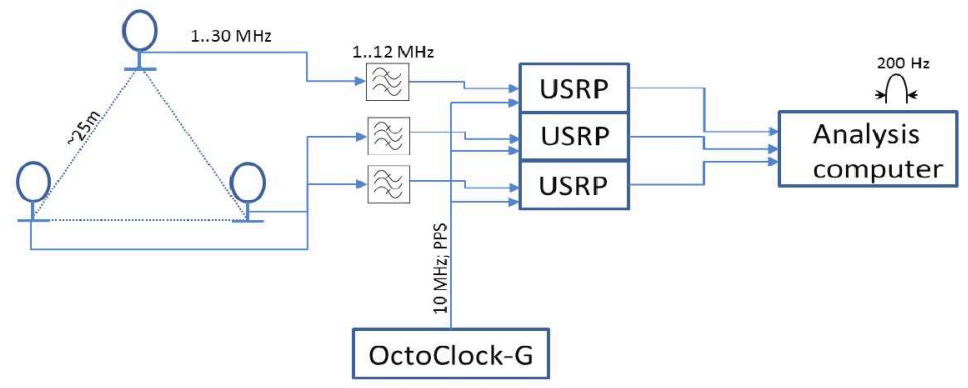

Fig. 4. Block diagram of the receiving system installed at "Palmer" station.

The system is based on software defined radio devices (USRP-210) which are synchronized by the external $10 \mathrm{MHz}$ reference source "OctoClock-G". The data are low-pass filtered and sampled at $100 \mathrm{Msamples} /$ second rate and transferred to the analysis computer, where it is band-pass filtered and decimated to $200 \mathrm{~Hz}$ rate with which it is saved in data files. The current software design allows simultaneous reception of three channels at three frequencies. Hardware band pass filters (1-12 MHz) are installed at the front end of the system to reduce the effect of out-of-band noise and interference.

Processing systems at the both receiving sites allow calculating dynamic spectrums of the CW probe signals in near real time. Observations of quasi-periodic variations of the Doppler frequency shift allow estimating TID parameters such as time period and apparent velocity along the "UAS-Palmer" direction.

\section{Observation results}

The analysis of the measured data on "UAS-Palmer" radio link has shown that quasi-periodic DFS variations are present during most of the observation time. An example of variations observed by both HF and GNSS instruments is presented in the Fig. 5 and Fig. 7 for the geomagnetically quiet conditions (beginning of 13th November 2015).

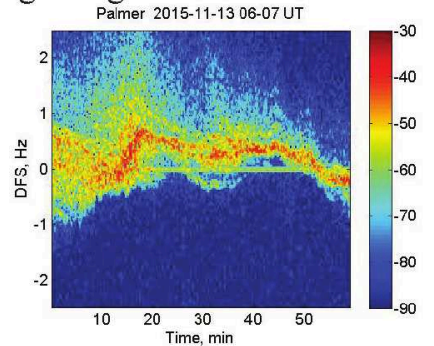

UAS 2015-11-13 06-07UT

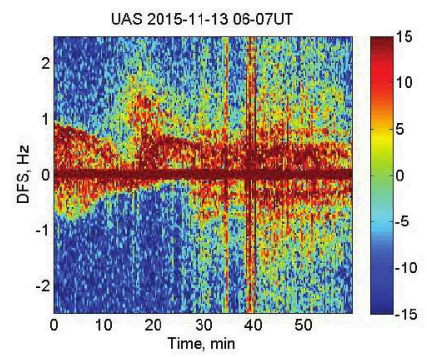

Pamer 2015-11-13 07-08 UT

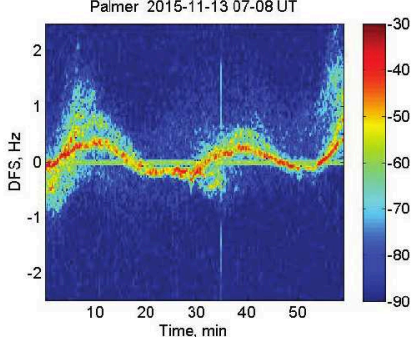

a)

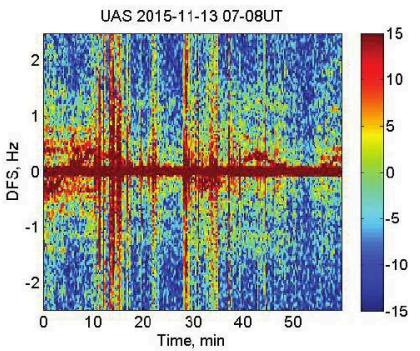

Palmer 2015-11-13 08-09 UT

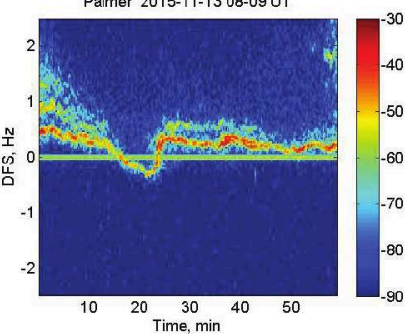

UAS 2015-11-13 08-09UT

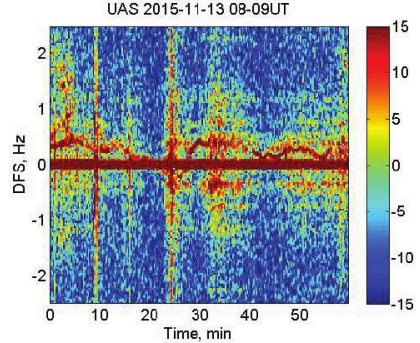

b)

Fig. 5. Doppler spectrogram of HF signal $\left(f_{w}=5.555 \mathrm{MHz}\right)$ recorded at "Palmer" (a) and UAS (b) stations on 2015.11.13, 6-9 UT.

Fig. 5 shows three one-hour spectrograms of the HF data collected on November 13, 2015 during 6-9 UT time interval. The upper panels present data for "Palmer", while lower panels for "Vernadsky" 
station. The traces of the "ground-wave" signal (with zero Doppler shift) and ionospherically reflected radio waves are clearly seen in the spectrograms. It is evident from the figures that during 7-8 UT the narrow spectral maximum quasi-periodically fluctuates with a period of approximately $30 \mathrm{~min}$ and amplitude of about $0.3 \mathrm{~Hz}$. The similar spectral features can also be seen in the spectrograms from UAS making it possible to detect a time shift between DFS fluctuations of the two positions. Estimated variations of DFS of the HF signal received at "Palmer" and "Vernadsky" stations on 2015.11.13 at 6-9 UT (Fig. 6a) demonstrate a very similar behavior.

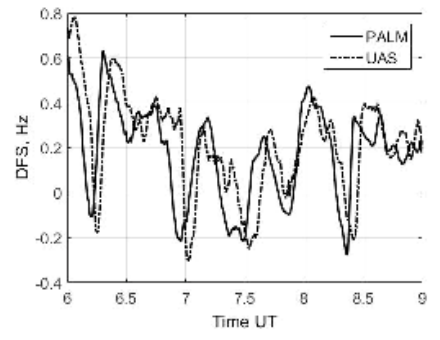

a)

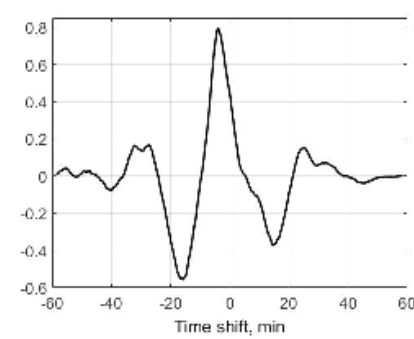

b)

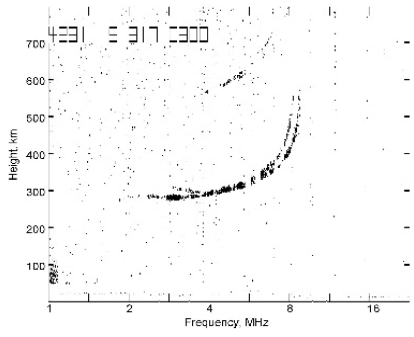

c)

Fig. 6. (a) Time variations of DFS of the HF signal $\left(f_{w}=5.555 \mathrm{MHz}\right)$ recorded at "Palmer" and "Vernadsky" stations on 2015.11.13 at 6-9 UT. (b) Cross-correlation function of DFS variations at UAS and "Palmer" during 8-9 UT. (c) Ionogram obtained at UAS on 13.11.2015 at 7 UT (03 LT).

The time delay between DFS at "Palmer" and UAS estimated using the cross-correlation function (Fig. 6b) is equal approximately 4 minutes. It allows determining a projection of the wave vector along "UAS-Palmer" radio link. Taking into account that HF signals received at "Palmer" station were reflected close to a mid-point of the radio path the corresponding apparent velocity along the "UAS-Palmer" direction was estimated as $\sim 112 \mathrm{~m} / \mathrm{s}$. The data of the simultaneous vertical ionospheric sounding (see Fig. 6c) indicate that the reflection of the probing signal occurred at the altitudes of F2 ionospheric layer. Such characteristics suggest that the observed variations were likely produced by the propagation of medium-scale AGW/TID.

Additionally, TEC fluctuations obtained from GNSS links whose ionospheric pierce points (IPPs) were located in close vicinity to the mid-point of the HF radio path have been considered. For time period of 7-8 UT the closest to the region of HF sounding were IPPs of the GPS satellites PRN03 and PRN32 therefore they were selected for further analysis. Trajectories of IPPs of GNSS links observed at PRPT for passes of these satellites are shown in Fig. 7a with dotted lines, and the period of 7-8 UT is highlighted with bold grey lines. The dashed circles show isolines of the distances of 200 and $50 \mathrm{~km}$ from mid-point of the HF radio path. The smoothed detrended TEC variations obtained from PRN03 and PRN32 at the stations PALM, DUPT and VNAD on 2015.11.13 at 6:30-8:30 UT are shown in Fig. 7b and 7c correspondingly.

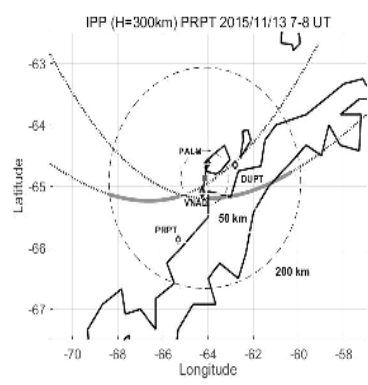

a)

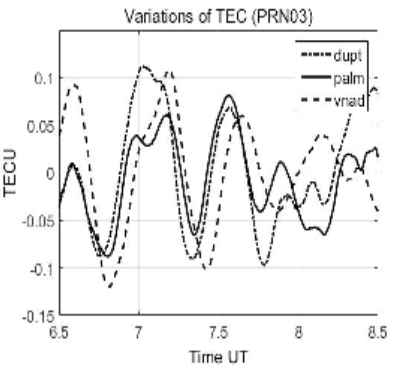

b)

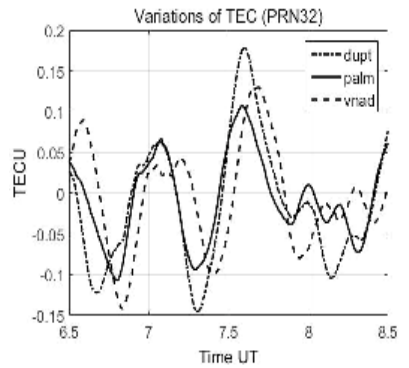

c)

Fig. 7. a) Trajectories of the ionospheric pierce points of GNSS ground-to-satellite links observed at PRPT in the vicinity of the "UAS-Palmer" on 13.11.2015 at 7-8 UT. The coordinates of IPPs were calculated using the thin-shell height $\mathrm{H}=300 \mathrm{~km} . \mathrm{b}, \mathrm{c}$ ) TEC variations obtained from PRN03 (b) and PRN32 (c) at stations PALM, DUPT and VNAD on 2015.11.13 at 6:30-8:30 UT. 
Similar quasi-periodic TEC variations with amplitude of about 0.1 TECU in all three spatially separated GNSS receivers can be seen in the data from each satellite. The similarity and quasi-periodic character of the TEC variations, and time shift between them confirm the presence of wavelike disturbances. Taking into account the high correlation between the data from different stations, the frozen-in propagation of the disturbance was supposed. The detrended TEC variations from these three stations, namely DUPT, PALM and VNAD, have been used to determine the propagation parameters of the ionospheric disturbances using equations (1).

The angular histograms of the disturbance propagation direction (azimuth) reconstructed using data of the GPS satellites PRN03 and PRN32 on 13.11.2015 from 7 to 8 UT are shown in Fig. 8. The histograms are attached to IPPs of GNSS links corresponding to GPS satellites observed at VNAD (dashed-dotted line) at 7:30 UT. It should be noted that azimuths were calculated using only those TEC measurements that satisfied the condition $|\gamma| \approx\left|\gamma_{0}\right| \geq 15 \cdot 10^{-4} \mathrm{TECU} / \mathrm{km}$, which is a requirement for the necessary accuracy of the azimuth calculation $\left(\sigma_{\alpha} \leq 10^{\circ}\right)($ Galushko et al., 2016).

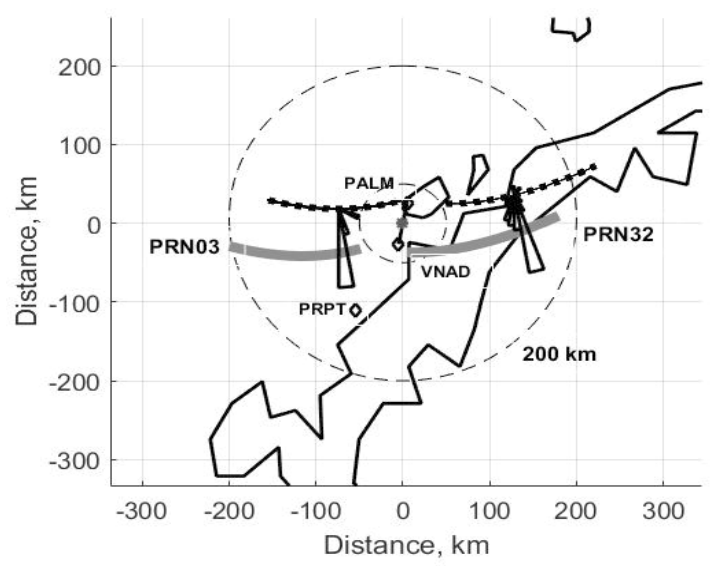

Fig. 8. Trajectories of the IPPs of GNSS link corresponding to GPS satellites PRN03 and PRN32 for VNAD (dashed-dotted line) and PRPT (bold grey line) on 13.11.2015 from 7 to 8 UT and the histograms of the reconstructed disturbance propagation direction (azimuth).

It can be seen that ionospheric irregularities propagate predominantly in the southern direction with average azimuths of about 175 and 165 degrees for PRN03 and PRN32 satellites correspondingly. The average velocities of the disturbances are approximately 98 and 100 m/s for PRN03 and PRN32 respectively. The spatial scale $\Lambda$ of the wave-like irregularities computed using velocity, azimuth, and positions of the disturbance's amplitude front is in the range of 180-260 km. All estimated parameters obtained for both satellites are very similar and consistent with the time period $(\mathrm{T}=\Lambda / \mathrm{V})$ and apparent velocity along the "UAS-Palmer" direction estimated from DFS variations (see Table 1). The obtained characteristics correspond to those of medium-scale AGW/TIDs (Hocke, 1996). It should be also noted that the distance between IPPs of PRN03 and PRN32 is about $200 \mathrm{~km}$ (see Fig. 8) suggesting that the width of the amplitude front is also of the same or larger size.

Table 1.

Parameters of TIDs estimated using GNSS (TEC) and HF (DFS) observations 2015.11.13 7-8 UT. The last column shows projections on the line of sight direction "UAS-Palmer" for wavelength and apparent velocity.

\begin{tabular}{|c|c|c|c|}
\hline & \multicolumn{2}{|c|}{ TEC measurements } & HF data \\
\hline & PRN03 & PRN32 & DFS \\
\hline $\mathrm{T},[\mathrm{min}]$ & $27-35$ & $32-34$ & $\sim 30$ \\
\hline$\alpha$ & $175^{\circ}$ & $165^{\circ}$ & - \\
\hline $\mathrm{Vm},[\mathrm{m} / \mathrm{s}]$ & 98 & 100 & 112 \\
\hline$\Lambda,[\mathrm{km}]$ & $175-235$ & $220-260$ & 201 \\
\hline
\end{tabular}


In the examined case the motion of IPPs of the GNSS links is almost perpendicular to the propagation direction of the disturbance (see Fig. 8). For this geometry TEC variation distortions due to IPP motion (the Doppler-like effect) should be minimal and the observed temporal fluctuations of TEC are caused mainly by TID propagation, i.e. TEC variations follow the waveform of an actual ionospheric disturbance and correspond to the ones that would have been observed at a fixed IPP. For further analysis, DFS variations and the rate of change (ROT) of detrended TEC have been compared (Fig. 9).
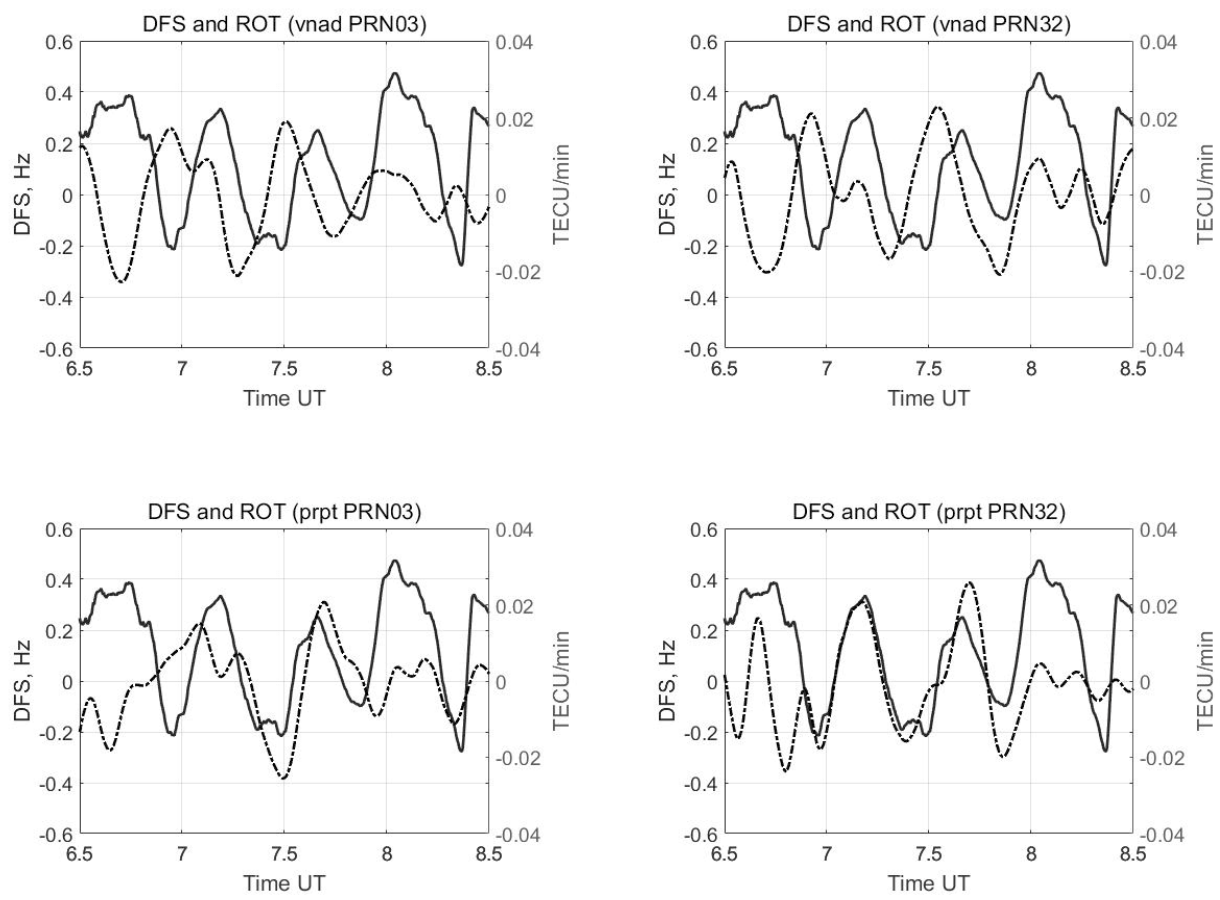

Fig. 9. Variations of DFS (solid line) of the HF signal received at "Palmer" station on 2015.11.13 at 6:30-8:30 UT and the rate of change of detrended TEC (dotted line) for GPS satellite PRN03 (left) and PRN32 (right) obtained at VNAD (upper panel) and PRPT (lower panel) stations.

It is worth noting that the periods of the variations observed with the two methods during the interval 7-8 UT are very similar. The observed time shifts between DFS and ROT fluctuations at spatially separated points correspond to North-South propagation of the ionospheric disturbance. These time shifts and corresponding IPP positions have been used to estimate wave parameters of the disturbances. The algorithm used to calculate the velocity and propagation direction is similar to D1-GPS method described in Afraimovich et al. (2006). It allows estimating the propagation parameters knowing the time shifts between similar extremums of variations at three observation points and their positions in space. In our case we used the positions of IPPs of PRN03 (PRN32) observed at VNAD and PRPT, taken at the time corresponding to the ROT minimum (maximum) as the first two registration points. The third registration point was the midpoint of the HF radio path. The calculated propagation direction (azimuth) is about $\alpha=165-195^{\circ}$ and the velocity range is $\mathrm{V}=80-145 \mathrm{~m} / \mathrm{s}$. The obtained characteristics are in a good accordance with estimated using GNSS-derived TEC and DFS fluctuations (see Table 1).

\section{Conclusions}

A bistatic coherent HF ionospheric sounding system was installed at the Antarctic Peninsula with a transmitter located at "Vernadsky" and a receiver at "Palmer" stations in May 2015. This system is used for detecting wavelike ionospheric disturbances and estimating their periods and the meridional projection of the wave vectors. Simultaneous observations of the same travelling ionospheric disturbances have been 
also conducted using GNSS-derived TEC technique. A case study performed in this work has shown that the spatial and temporal parameters of the ionospheric disturbances assessed by the two methods are in a good agreement. In the case under consideration the wavelike disturbances propagated almost in the meridional direction from North to South with the azimuthal angle of about 170 degrees. Their time period was $30 \mathrm{~min}$; velocity and spatial scale were estimated to be about $100 \mathrm{~m} / \mathrm{s}$ and $230 \mathrm{~km}$, correspondingly.

The results demonstrate that the effectiveness and accuracy of the TID diagnostics could be significantly improved by performing simultaneous measurements using both Doppler HF and GNSS-TEC techniques. The proposed technique will be used to determine regular variations of TID parameters and to establish the relationship between TID parameters and tropospheric weather and geomagnetic activities, and to identify their sources.

Acknowledgments. This study has been carried out with the support of NASU Projects "Yatagan-3" (0116U000035), "Heliomax-2016"(0116U005694c), and "Spitsbergen-16" (0116U002874), and with partial support of EOARD-STCU partner project P667, and NSF project \#1341557.

This material is based on data services provided by the UNAVCO Facility with support from the National Science Foundation (NSF) and National Aeronautics and Space Administration (NASA) under NSF Cooperative Agreement No. EAR-0735156.

\section{References}

1. Afraimovich E. L. and Perevalova N. P. GPS-monitoring verkhnei atmosfery Zemli (GPS Monitoring of the Earth's Upper Atmosphere), Irkutsk: GU NTs RVKh VSNTs SO RAMN. - 2006. - 480 p. (in Russian).

2. Beley V. S., Galushko V. G., Yampolski Y. M. Traveling ionospheric disturbance diagnostics using HF signal trajectory parameter variations // Radio Science. - 1995. - Vol. 30, Is. 6. - P. 1739 - 1752. doi:10.1029/95RS01992.

3. Galushko V. G., Kashcheyev A. S., Kashcheyev S. B. et al. Bistatic HF diagnostics of TIDs over the Antarctic Peninsula // Journal of Atmospheric and Solar-Terrestrial Physics. - 2007. - Vol. 69. - P. 403 - 410.

4. Galushko V. G., Paznukhov V. V., Sopin A. A. et al. Statistics of ionospheric disturbances over the Antarctic Peninsula as derived from TEC measurements // J. Geophys. Res. Space Physics. - 2016. - Vol 121. doi:10.1002/2015JA022302.

5. Grocott A., Hosokawa K., Ishida T. et al. Characteristics of medium-scale traveling ionospheric disturbances observed near the Antarctic Peninsula by HF radar // J. Geophys. Res. Space Physics. - 2013. - Vol. 118. P. 5830 - 5841. doi:10.1002/jgra.50515.

6. Hocke K., Schlegel K. A review of atmospheric gravity waves and travelling ionospheric disturbances: 1982-1995 // Ann. Geophys. - 1996. - Vol. 14. - P. 917 - 940. doi:10.1007/s00585-996-0917-6.

7. Paznukhov V. V., Galushko V. G., Reinisch B. W. Digisonde observations of AGWs/TIDs with Frequency and Angular Sounding Technique // Advances in Space Research. - 2012. - Vol. 49, Is. 4. - P. $700-710$. doi:10.1016/j.asr.2011.11.012.

8. Sopin A. O., Zanimonskiy Y. M., Lisachenko V. N. et al. Features of background variations in total electron content of ionosphere over the Antarctic Peninsula // Radio Physics and Radio Astronomy. - 2012. - Vol. 17. - P. 49 56. (in Russian).

9. Yampolski Y. M., Zalizovsky A. V., Lytvynenko L. M. et al. Magnetic field variations in Antarctica and the conjugate region (New England) stimulated by cyclone activity // Radio Physics and Radio Astronomy. - 2004. -Vol. 9. - P. 130 - 151. (in Russian).

10. Zalizovski A. V. and Yampolski Y. M. The spread-F effect as an indicator of troposphere-ionosphere coupling // Radio physics and radio astronomy. - 2007. -Vol. 12. - P. 33 - 42. (in Russian). 